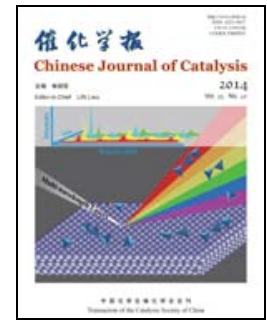

Article

\title{
Epoxidation of vinyl functionalized cubic Ia3d mesoporous silica for immobilization of penicillin G acylase
}

\author{
Wangcheng Zhan, Yongjun Lü, Ling Yang, Yanglong Guo, Yanqin Wang, Yun Guo, Guanzhong Lu* \\ Key Laboratory for Advanced Materials, Research Institute of Industrial Catalysis, East China University of Science and Technology, Shanghai 200237, \\ China
}

A R T I C L E I N F O

Article history:

Received 24 March 2014

Accpeted 15 April 2014

Published 20 October 2014

\section{Keywords:}

Co-condensation method

Mesoporous silica

Enzyme

Immobilization

Penicillin $\mathrm{G}$ acylase

\begin{abstract}
A B S T R A C T
Epoxy functionalized cubic Ia $d$ mesoporous silica (CIMS) was successfully synthesized by epoxidizing vinyl groups prepared on the CIMS by a co-condensation method. The synthesized material was characterized by X-ray diffraction, nitrogen sorption, transmission electron microscopy, thermogravimetric analysis, and solid state ${ }^{13} \mathrm{C}$ NMR. The vinyl groups were found to be easily epoxidized to yield epoxy functionalized CIMS. The epoxy functionalized CIMS was used as a support for the immobilization of penicillin G acylase (PGA), and the effects of the epoxy group on the initial activity and the operational stability of the immobilized PGA were studied. The results showed that the enzyme loading and initial activity of the immobilized PGA decreased with increasing amounts of epoxy groups. These observations were due to a decrease in the pore size of the mesoporous silica as well as an increase in the hydrophobicity of the silica surface. However, an appropriate amount of epoxy groups on the CIMS support was found to improve the operational stability of the immobilized PGA. This improvement was the result of increased interactions between the epoxy functionalized CIMS support and the PGA.
\end{abstract}

(C) 2014, Dalian Institute of Chemical Physics, Chinese Academy of Sciences. Published by Elsevier B.V. All rights reserved.

\section{Introduction}

Enzymes are excellent catalysts with high chemo-, regio-, stereo-, and chiral-selectivity under mild conditions. However, their strong sensitivity to temperature, high cost, and difficulty in recovering active enzyme for reuse currently limit their industrial application [1,2]. Immobilization of enzymes can overcome these disadvantages, and many kinds of supports have been studied [3-7]. Owing to its highly ordered pore structure, large tunable pore diameter, high pore volume, and narrow pore size distribution, ordered mesoporous silica is a widely applicable support for the immobilization of enzymes and can achieve a high activity per unit volume [8-12]. However, interaction between enzymes and ordered mesoporous silica is very weak, and the enzymes can be easily washed off during the catalytic process, resulting in poor operational stability [13]. Functionalization of the surface of mesoporous silica with organic groups can enhance its interaction with enzymes [14-17].

Post-synthesis grafting and co-condensation are currently the most common methods for functionalizing the surface of mesoporous silica with organic groups [18-21]. Compared with co-condensation, post-synthesis grafting has many disadvantages [22], such as the nonuniform distribution of the or-

\footnotetext{
*Corresponding author. Tel/Fax: +86-21-64252923; E-mail: gzhlu@ecust.edu.cn This work was supported by the National Natural Science Foundation of China (21103048), the Program for New Century Excellent Talents in University (NCET-09-0343), and Shuguang Project of Shanghai Municipal Education Commission and Shanghai Education Development Foundation (10SG30). 
ganic groups created on the surface of the mesoporous silica. A large proportion of these organic groups appear on the external surface of the mesoporous silica or inside channels but near the channel openings [5]. Furthermore, the pore size and pore volume of the mesoporous silica, which greatly impact the activity of an immobilized enzyme [23-25], may be substantially decreased after post-synthesis grafting [26]. In contrast, the co-condensation method can be used to functionalize the surface of mesoporous silica in a single step via copolymerization of an organosilane with the silica precursor in the presence of a surfactant template [27-30]. This method results in a highly homogeneous distribution of the organic groups on the surface of the mesoporous silica [31,32].

Epoxy functionalized supports can immobilize enzymes through reaction between epoxy groups and the amino groups $\left(\mathrm{NH}_{2}{ }^{-}\right)$of the enzymes under mild conditions [33-36]. However, the conditions used to synthesize ordered mesoporous silica are usually strongly acidic, and epoxy groups cannot exist under such severe conditions, making co-condensation impossible. However, vinyl functionalized ordered mesoporous silica is easily synthesized by co-condensation [37-39], and the vinyl groups can be easily epoxidized $[40,41]$. This method enables epoxy groups to be uniformly distributed on the surface of mesoporous silica.

Cubic Ia3d mesoporous silica (CIMS) has recently received great attention owing to its large uniform pores (5-12 $\mathrm{nm}$ ) and 3D interpenetrating bicontinuous networks of channels, which allow easy accessibility and fast transport of molecules [42-44]. Thus, enzymes immobilized on CIMS can achieve a high activity. However, the epoxidation of vinyl functionalized CIMS and its subsequent application to the immobilization of enzymes have not previously been reported.

In this paper, vinyl functionalized CIMS was synthesized by a co-condensation method and then epoxidized, and the epoxy functionalized CIMS was used as a support for the immobilization of penicillin $\mathrm{G}$ acylase (PGA). The influence of the epoxy groups on the initial activity and the operational stability of the immobilized PGA biocatalysts were studied.

\section{Experimental}

\subsection{Chemicals}

Non-ionic triblock copolymer P123 (EO20P070EO20, MW = 5800, Aldrich), tetraethyl orthosilicate (TEOS), $m$-chloroperbenzoic acid ( $m$-CPBA, 50\%-55\%, Alpha-Aesar), and vinyl triethoxysilane (VTES; Haida, China) were used in this work. PGA (804 U/mL) was purchased from Hiader Co. Ltd, Zhejiang, China. Penicillin $G$ potassium salt was purchased from Shandong Lukang Pharmaceutical Co. Ltd., China. $\mathrm{NaOH}$ solution and phosphate buffer were prepared according to the literature [45]. $m$-CPBA was dried with anhydrous magnesium sulfate $\left(\mathrm{MgSO}_{4}\right) . \mathrm{m}$-CPBA (2 g) and $\mathrm{MgSO}_{4}(4 \mathrm{~g})$ were added to $100 \mathrm{~mL}$ dichloromethane, after which the mixture was stirred to completely remove the water from the solution and then filtered. The concentration of $m$-CPBA in the dichloromethane was about $0.02 \mathrm{~g} / \mathrm{mL}$. All other chemicals were analytical grade and were used as received.

\subsection{Synthesis of vinyl functionalized CIMS (V-CIMS)}

As-synthesized V-CIMS was prepared according to the literature [38]. $\mathrm{P} 123$ (5.68 g) and $\mathrm{Na}_{2} \mathrm{SO}_{4}$ (11.36 g) were dissolved in $160 \mathrm{~mL}$ of $\mathrm{HCl}(1 \mathrm{~mol} / \mathrm{L})$, and the mixture was stirred at 35 ${ }^{\circ} \mathrm{C}$ for $4 \mathrm{~h}$. Then, $53.2 \mathrm{mmol}$ of TEOS and 5-20 wt\% VTES was added slowly under stirring. After continuous stirring at $35{ }^{\circ} \mathrm{C}$ for $24 \mathrm{~h}$, the synthesis solution was transferred into a polypropylene bottle and crystallized at $100{ }^{\circ} \mathrm{C}$ for $24 \mathrm{~h}$. The as-synthesized V-CIMS product was collected by filtration and dried overnight at $100^{\circ} \mathrm{C}$.

The P123 template was removed from the as-synthesized V-CIMS by extraction [46-48]. The as-synthesized V-CIMS (1.0 g) was mixed with $50 \mathrm{~mL}$ of $60 \mathrm{wt} \% \mathrm{H}_{2} \mathrm{SO}_{4}$ solution, and the mixture was stirred at $95^{\circ} \mathrm{C}$ for $24 \mathrm{~h}$. The product was collected by filtration, washed successively with water and ethanol, and dried at $90{ }^{\circ} \mathrm{C}$ for $24 \mathrm{~h}$ under vacuum. The prepared samples were named V-CIMS(5\%-20\%), where the number in the bracket was the mass percent of VTES in the silica precursor.

\subsection{Epoxidation of V-CIMS}

The epoxidation of V-CIMS was carried out at $35{ }^{\circ} \mathrm{C}$ in dichloromethane. V-CIMS ( $0.5 \mathrm{~g}$ ) was mixed with $50 \mathrm{~mL}$ of the dichloromethane solution with $m$-CPBA, and the mixture was refluxed at $35{ }^{\circ} \mathrm{C}$ for $72 \mathrm{~h}$ under stirring. The resulting epoxy functionalized product, named E-CIMS(5\%-20\%), was collected by filtration, washed three times with dichloromethane, and dried under vacuum for $24 \mathrm{~h}$.

\subsection{Immobilization of PGA on E-CIMS supports}

The E-CIMS support $(0.1 \mathrm{~g})$ was added to $5 \mathrm{~mL}$ of the enzyme solution (PGA, $804 \mathrm{U} / \mathrm{mL}$ ) diluted with $0.1 \mathrm{~mol} / \mathrm{L}$ of $\mathrm{pH}=$ 7.8 phosphate buffer $\left(V_{\text {enzyme}} / V_{\text {buffer }}=1 / 4\right)$. The mixture was shaken at $30{ }^{\circ} \mathrm{C}$ for $24 \mathrm{~h}$ at $130 \mathrm{rpm}$. The immobilized PGA was then filtered and washed with de-ionized water and buffer, after which the wet immobilized enzyme (IME) was ready for initial activity and operational stability testing.

\subsection{Initial activity and operational stability tests}

The enzyme activity of the immobilized PGA was evaluated by titrating phenylacetic acid (PAA), a by-product in the hydrolysis reaction of penicillin $G$ potassium salt (Scheme 1). The formation of PAA lowers the $\mathrm{pH}$ of the hydrolysis mixture solution. The activity of PGA can be determined by titrating the produced PAA with $\mathrm{NaOH}$ solution until the initial $\mathrm{pH}$ of the

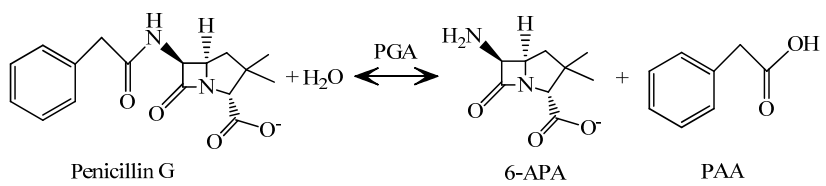

Scheme 1. Hydrolysis of penicillin G catalyzed by penicillin G acylase (PGA). 
reaction solution is reached. The amount of PAA produced is calculated based on the volume of $\mathrm{NaOH}$ consumed during the first $10 \mathrm{~min}$. This equals the molar amount of 6-APA formed, allowing the enzyme activity of the immobilized PGA to be obtained.

The procedure used to test the activity of the immobilized PGA was as follows. The as-separated immobilized PGA mentioned above was homogenously mixed with $10 \mathrm{~mL}$ deionized water and $5 \mathrm{~mL}$ phosphate buffer $(0.1 \mathrm{~mol} / \mathrm{L}, \mathrm{pH}=7.8)$ at $37^{\circ} \mathrm{C}$ in a thermostatic bath, and then $30 \mathrm{~mL} 4 \%$ (m/v) aqueous solution of penicillin $\mathrm{G}$ potassium salt kept at $37^{\circ} \mathrm{C}$ was added. The mixed solution was automatically titrated with $\mathrm{NaOH}$ solution $(0.1 \mathrm{~mol} / \mathrm{L})$ to maintain $\mathrm{pH}=7.8$, and the volume of $\mathrm{NaOH}$ consumed during the first 10 min was measured. The activity of the immobilized PGA was calculated as follows:

$$
A(\mathrm{U} / \mathrm{g})=V_{\mathrm{NaOH}} \cdot C_{\mathrm{NaOH}} \cdot 10^{3} /(m \cdot t)
$$

where $V_{\mathrm{NaOH}}$ is the volume $(\mathrm{mL})$ of $\mathrm{NaOH}$ solution consumed, $C_{\mathrm{NaOH}}$ is the concentration (mol/L) of the $\mathrm{NaOH}$ solution, $m$ is the amount (g) of dry support, and $t$ is the reaction time (min, i.e., $10 \mathrm{~min}$ ).

The operational stability test was carried out as follows. After testing the initial activity, the solution was separated by centrifugation at $3000 \mathrm{rpm}$ for $5 \mathrm{~min}$, and then the upper water layer was quickly removed. The remnant solid was transferred into a kettle reactor, and its activity was tested by the same method as that mentioned above.

\subsection{Characterization}

Powder X-ray diffraction (XRD) patterns were collected on a Rigaku D/max-2550VB/PC with $\mathrm{Cu} K_{\alpha}$ radiation at $40 \mathrm{kV}$ and $200 \mathrm{~mA}$. $\mathrm{N}_{2}$ adsorption-desorption isotherms were measured at $-196{ }^{\circ} \mathrm{C}$ on a Micromeritics ASAP 2020M Sorptometer. Prior to analysis, the functionalized samples were degassed overnight at $110{ }^{\circ} \mathrm{C}$ under vacuum, and the unfunctionalized samples were degassed at $350{ }^{\circ} \mathrm{C}$ for more than $6 \mathrm{~h}$. The BJH pore size distributions were obtained from the desorption branch of the isotherm using Halsey's thickness equation. Thermogravimetric analyses (TGA) were carried out on a Perkin Elmer thermogravimetric analyzer in air from 30 to $650{ }^{\circ} \mathrm{C}$. Solid state ${ }^{13} \mathrm{C}$ nuclear magnetic resonance (NMR) analysis was performed on a Bruker (Germany) Avance $500 \mathrm{MHz}$ NMR spectrometer. TEM images were obtained on a TECNAI 20S-TWIN electron microscope. Prior to analysis, the samples were dispersed in ethanol by sonication for $20 \mathrm{~min}$ and then dropped on a copper grid coated with carbon film.

\section{Results and discussion}

\subsection{Characterization of functionalized CIMS}

The XRD patterns of V-CIMS samples and E-CIMS(10\%) are shown in Fig. 1. V-CIMS(5\%) exhibited two diffraction peaks at $2 \theta=1.41^{\circ}$ and $1.65^{\circ}$, indicating its hexagonal $p 6 \mathrm{~mm}$ structure. These two diffraction peaks disappeared, and a shoulder peak arose at $2 \theta=0.98^{\circ}$ with increasing amount of VTES in the synthesis solution, which indicated the transformation of the

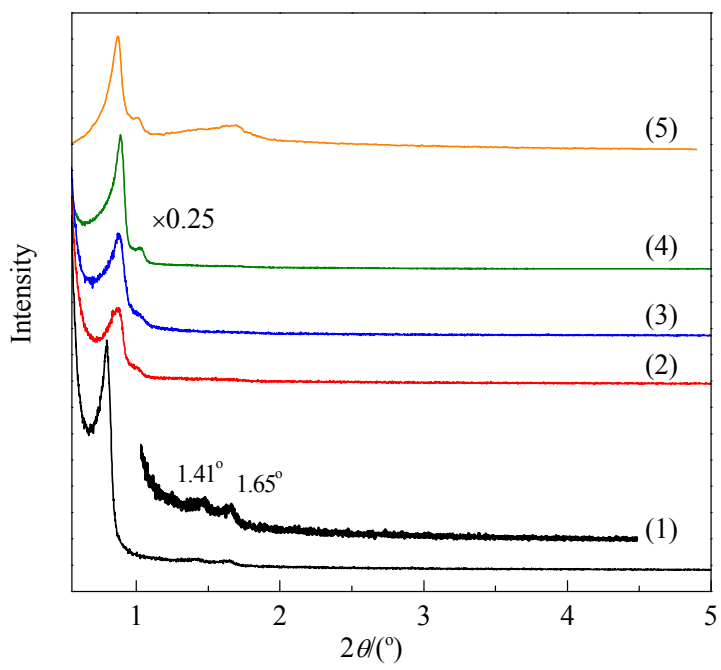

Fig. 1. XRD patterns of V-CIMS(5\%) (1), V-CIMS(10\%) (2) V-CIMS(15\%) (3), V-CIMS(20\%) (4), and E-CIMS(10\%) (5).

mesoporous structure from the hexagonal $p 6 \mathrm{~mm}$ structure to the cubic Ia3d phase. In the case of V-CIMS(20\%), the cubic Ia3d phase was fully developed. These results agree well with the results reported in the literature $[37,38]$, confirming the successful synthesis of vinyl functionalized CIMS.

As shown in Fig. 1(5), E-CIMS(10\%) exhibited three diffraction peaks at $2 \theta=0.97^{\circ}, 1.11^{\circ}$, and $1.78^{\circ}$, indicating that the cubic Ia3d structure was maintained during the epoxidation. TEM images of V-CIMS(10\%) and E-CIMS(10\%) are shown in Fig. 2. The ordered pore arrays could be clearly observed in the TEM images of both samples, which further confirmed that the epoxidation did not destroy the mesostructure of CIMS.

The $\mathrm{N}_{2}$ adsorption-desorption isotherms of V-CIMS(10\%) and E-CIMS(10\%) are shown in Fig. 3. The isotherm of V-CIMS(10\%) exhibited the typical type IV isotherms of mesoporous materials with a sharp ramp in the relative pressure range of $0.6-0.8$, caused by the capillary condensation of $\mathrm{N}_{2}$ in the pores [49]. Similarly, the isotherm of E-CIMS(10\%) also showed the characteristic step of the isotherm of V-CIMS(10\%), and the capillary condensation step appeared in the same relative pressure range. However, the isotherm of PGA/E-CIMS (10\%) exhibited almost a straight line (not shown), indicating that the vast majority of the pores of the E-CIMS was filled with PGA. The textural properties of V-CIMS(10\%) and E-CIMS $(10 \%)$ are listed in Table 1 . The BET surface area, pore size,

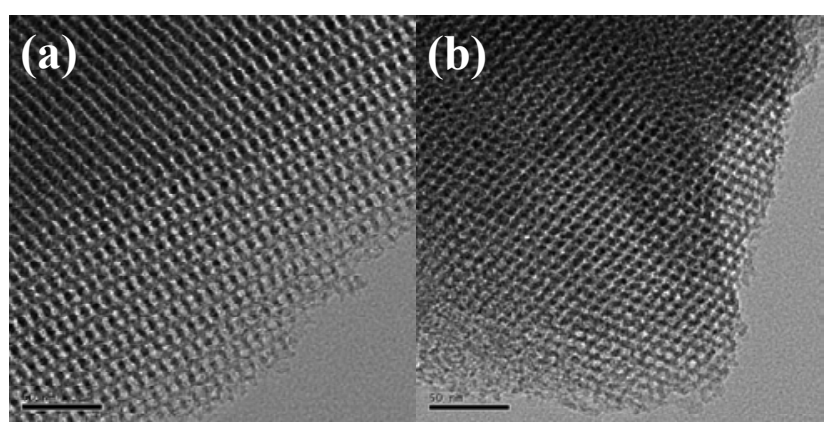

Fig. 2. TEM images of V-CIMS(10\%) (a) and E-CIMS(10\%) (b). 


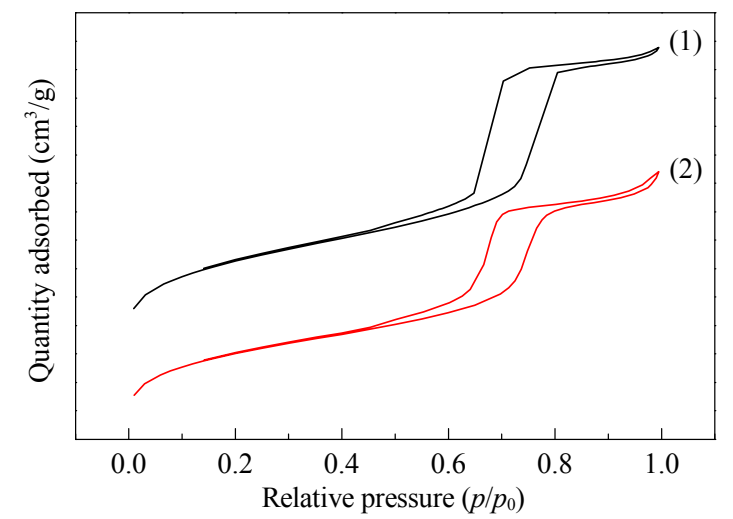

Fig. 3. Nitrogen adsorption-desorption isotherms of V-CIMS(10\%) (1) and E-CIMS(10\%) (2).

Table 1

Textural properties of V-CIMS(10\%) and E-CIMS(10\%).

\begin{tabular}{lccc}
\hline Sample & $\begin{array}{c}\text { Surface area } \\
\left(\mathrm{m}^{2} / \mathrm{g}\right)\end{array}$ & $\begin{array}{c}\text { Pore volume } \\
\left(\mathrm{cm}^{3} / \mathrm{g}\right)\end{array}$ & $\begin{array}{c}\text { Pore size } \\
(\mathrm{nm})\end{array}$ \\
\hline V-CIMS $(10 \%)$ & 548 & 0.73 & 7.1 \\
E-CIMS $(10 \%)$ & 537 & 0.71 & 6.9 \\
\hline
\end{tabular}

and pore volume of V-CIMS(10\%) were close to those of E-CIMS(10\%), indicating that the epoxidation process hardly influenced the mesoporous structure of V-CIMS(10\%). This was because the epoxidation of the vinyl groups did not increase or decrease the carbon chains of the organic groups on the surface of the CIMS.

Fig. 4 shows the pore size distributions of the E-CIMS samples, which were all very narrow. However, the pore size of E-CIMS decreased with increasing amount of epoxy groups. The average pore size of E-CIMS(5\%) was $7.2 \mathrm{~nm}$, while that of E-CIMS(20\%) was $6.2 \mathrm{~nm}$.

Fig. 5 shows the TG curves of as-synthesized V-CIMS(10\%) and V-CIMS(10\%) after the removal of the P123 template. Two mass losses were observed in the TG curve of as-synthesized V-CIMS(10\%). The first, from 150 to $240{ }^{\circ} \mathrm{C}$, was attributed to the combustion of the P123 template, while the other from 240

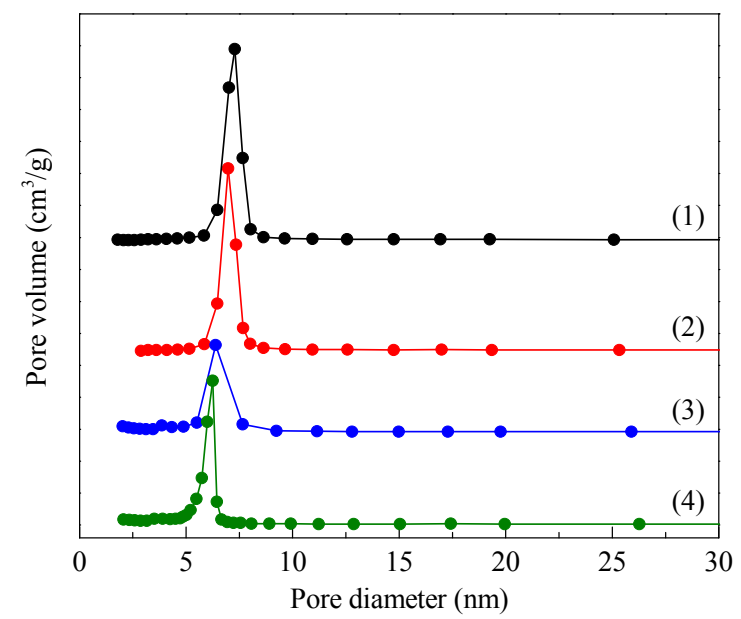

Fig. 4. Pore size distribution curves of E-CIMS(5\%) (1), E-CIMS(10\%) (2), E-CIMS(15\%) (3), and E-CIMS(20\%) (4).

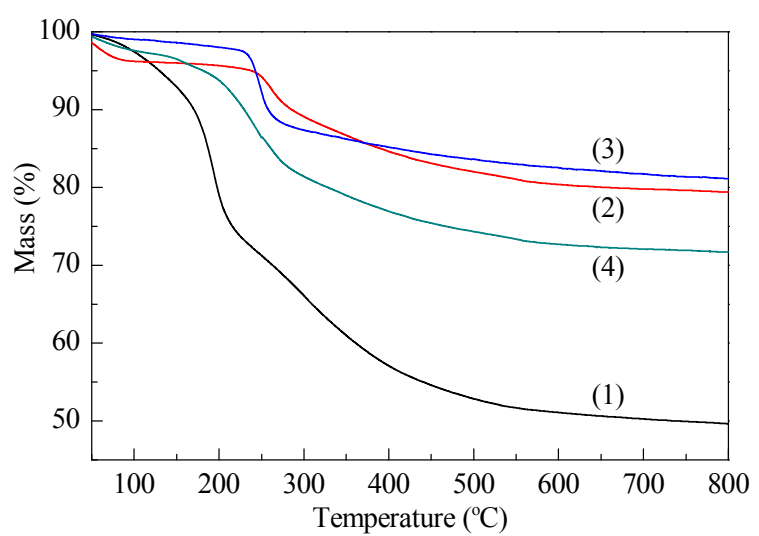

Fig. 5. TG curves of as-synthesized V-CIMS(10\%) (1), V-CIMS(10\%) after the removal of P123 template (2), E-CIMS(20\%) (3), and PGA/E-CIMS(20\%) (4).

to $450{ }^{\circ} \mathrm{C}$ was attributed to the combustion of P123 template remaining inside the sample and the vinyl groups. However, there was only one mass loss (from 250 to $400{ }^{\circ} \mathrm{C}$ ) in the TG curve of V-CIMS(10\%), which was assigned to the combustion of P123 template remaining in the sample and the vinyl groups. Therefore, the TG results indicated that the majority of the P123 template had been removed from as-synthesized V-CIMS(10\%) by the acid treatment.

TG curves of E-CIMS(20\%) and PGA/E-CIMS(20\%) are also shown in Fig. 5. E-CIMS(20\%) had a remarkable mass loss at $210-300^{\circ} \mathrm{C}$, which was attributed to combustion of the epoxy groups on the surface of CIMS and remaining P123 template. Compared with E-CIMS(20\%), the PGA/E-CIMS(20\%) exhibited much greater mass loss due to the combustion of the immobilized PGA and organic functional groups grafted on the surface of the E-CIMS(20\%). These results indicated that the PGA enzyme had been immobilized on the E-CIMS(20\%) support.

The solid state ${ }^{13} \mathrm{C}$ NMR spectrum of as-synthesized V-CIMS(20\%) is shown in Fig. 6. Three resonance peaks at $162.2,70.1$, and 16.2 ppm were observed. The resonance peaks at 70.1 and $16.2 \mathrm{ppm}$ were attributed to the carbon of the P123 template. Comparing the ${ }^{13} \mathrm{C}$ NMR of as-synthesized V-CIMS (20\%) with that of VTES, the resonance peak at $162.2 \mathrm{ppm}$ was assigned to the carbons of vinyl groups on as-synthesized V-CIMS(20\%), indicating the successful incorporation of vinyl groups on the surface of this sample. However, the chemical shift of the carbons in the vinyl groups of as-synthesized

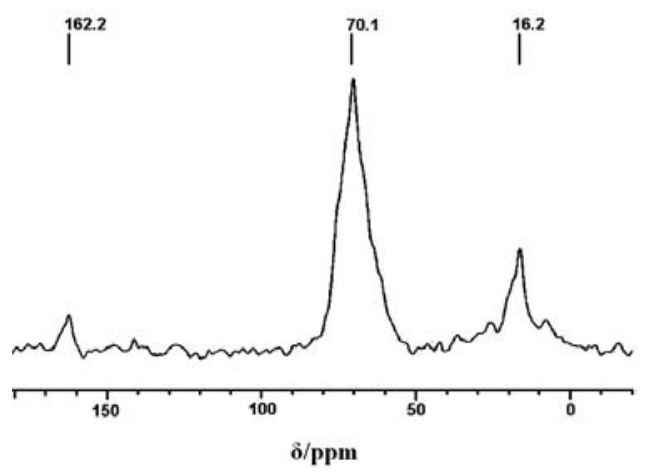

Fig. 6. Solid state ${ }^{13} \mathrm{C}$ NMR spectrum of as-synthesized V-CIMS(20\%). 
<smiles>C=C(C)[Si](OC)(OCC)OCC</smiles><smiles>C=C[Si](O[Si])(O[Si])O[Si]</smiles>

V-CIMS Epoxy group on E-CIMS

Fig. 7. Scheme of VTES and epoxy group on the surface of E-CIMS.

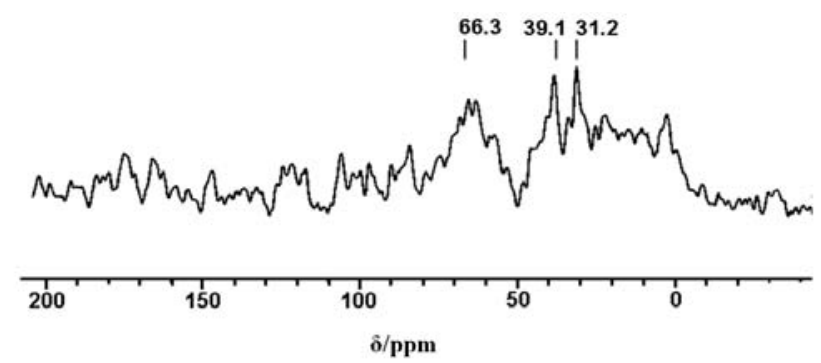

Fig. 8. Solid state ${ }^{13} \mathrm{C}$ NMR spectrum of E-CIMS(20\%).

V-CIMS ( $\mathrm{C}_{1^{\prime}}$ and $\mathrm{C}_{2^{\prime}}$ of V-CIMS in Fig. 7) was moved to higher field, which was attributed to their different chemical environment. Most importantly, the vinyl groups of as-synthesized V-CIMS were in a solid state while the vinyl groups of VTES were in a liquid state.

The solid state ${ }^{13} \mathrm{C}$ NMR spectrum of E-CIMS(20\%) is shown in Fig. 8. Three resonance peaks at 66.3, 39.1, and $31.2 \mathrm{ppm}$ were present. The resonance peaks at 39.1 and $31.2 \mathrm{ppm}$ were attributed to the carbons of the epoxy groups on E-CIMS, indicating the successful epoxidation of the vinyl groups of V-CIMS(20\%). The resonance peak at $66.3 \mathrm{ppm}$ was attributed to the carbons of remaining P123 template, as shown in the TG results (Fig. 5). These P123 template agents were probably located in the micropores of CIMS and were thus very difficult to extract with $\mathrm{H}_{2} \mathrm{SO}_{4}$.

\subsection{Performance of immobilized PGA}

Table 2 shows the enzyme loading, initial activity, and operational stability of PGA immobilized on E-CIMS. The initial activity of the immobilized PGA was found to be lower than that of the free enzyme ( $13200 \mathrm{U} / \mathrm{g})$. The enzyme loading and the initial activity of PGA/E-CIMS decreased with increasing amount of epoxy groups. There were two reasons for this phenomenon. The decrease in the pore size of E-CIMS blocked PGA

Table 2

Enzyme loading, initial activity, and operational stability of immobilized PGA.

\begin{tabular}{lcccc}
\hline Sample & $\begin{array}{c}\text { PGA loading } \\
\text { (mg/g) }\end{array}$ & $\begin{array}{c}\text { Initial activity } \\
\text { (U/g) }\end{array}$ & Ratio $^{\mathrm{a}}$ & $\begin{array}{c}\text { Operational } \\
\text { stability }(\%)\end{array}$ \\
\hline PGA/E-CIMS(5\%) & 209 & 3611 & 0.274 & 76.5 \\
PGA/E-CIMS(10\%) & 125 & 2262 & 0.171 & 79.9 \\
PGA/E-CIMS(15\%) & 77 & 1563 & 0.118 & 65.6 \\
PGA/E-CIMS(20\%) & 63 & 1308 & 0.099 & 63.4 \\
\hline
\end{tabular}

a Ratio of the initial activity of immobilized PGA to that of the free enzyme. ${ }^{b}$ Ratio of the activity of immobilized PGA after five uses to its initial activity.

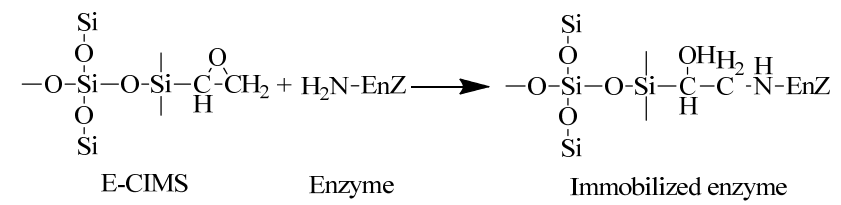

Scheme 2. Enzyme immobilization on E-CIMS.

molecules from entering into the channels, resulting in fewer PGA molecules immobilized on the support and a corresponding decrease in the initial activity of PGA/E-CIMS. In addition, the incorporation of epoxy groups on CIMS may increase the hydrophobicity of its surface [16,50,51], which was unfavorable for the contact of water-soluble PGA and reaction substrate with E-CIMS, leading to the decrease in the initial activity of immobilized PGA.

The operational stability of PGA/E-CIMS is also shown in Table 2. The operational stability initially increased with increasing amount of epoxy groups on the E-CIMS surface and then decreased with the further increase in the amount of epoxy groups. PGA/E-CIMS(10\%) exhibited the highest operational stability, achieving $79.7 \%$ of its initial activity after five cycles. Compared with E-CIMS(5\%), the E-CIMS(10\%) sample possessed more epoxy groups, which enhanced the interaction of E-CIMS support and PGA through chemical bonding (Scheme 2), leading to the improved operational stability of the E-CIMS(10\%) sample. However, with further increase in the amount of epoxy groups on the E-CIMS surface, i.e., E-CIMS (15\%) and E-CIMS(20\%) samples, the pore size and pore volume of the E-CIMS was greatly decreased, which blocked PGA molecules from entering the channels of the CIMS. As a result, more PGA molecules were immobilized on the external surface of E-CIMS or inside channels but near the channel opening. These PGA molecules could be easily washed off during the biocatalytic process, resulting in decreased operational stability of the PGA/E-CIMS.

\section{Conclusions}

Vinyl functionalized cubic Ia3d mesoporous silica was successfully synthesized by co-condensation, and the vinyl groups were epoxidized to prepare epoxy functionalized cubic Ia3d mesoporous silica (E-CIMS). The obtained E-CIMS was used as the support for the immobilization of PGA. The enzyme loading of PGA/E-CIMS(5\%) was $209 \mathrm{mg} / \mathrm{g}$ and its initial activity was $3611 \mathrm{U} / \mathrm{g}$. The enzyme loading and the initial activity of the immobilized PGA decreased with increasing amount of epoxy groups. However, the operational stability of PGA/E-CIMS increased with the amount of epoxy groups on the E-CIMS surface and then decreased with further increases in the amount of epoxy groups. PGA/E-CIMS(10\%) exhibited the highest operational stability, achieving $79.7 \%$ of its initial activity after five uses. This work therefore provides an efficient way to improve the operational stability of immobilized enzymes. However, it would be preferable to use mesoporous materials with larger pore size and pore volume to enhance the interaction between the epoxy groups and the enzyme. 


\section{Graphical Abstract}

Chin. J. Catal., 2014, 35: 1709-1715 doi: 10.1016/S1872-2067(14)60156-X

Epoxidation of vinyl functionalized cubic Ia $3 \mathrm{~d}$ mesoporous silica for immobilization of penicillin G acylase

Wangcheng Zhan, Yongjun Lü, Ling Yang, Yanglong Guo, Yanqin Wang, Yun Guo, Guanzhong Lu*

East China University of Science and Technology

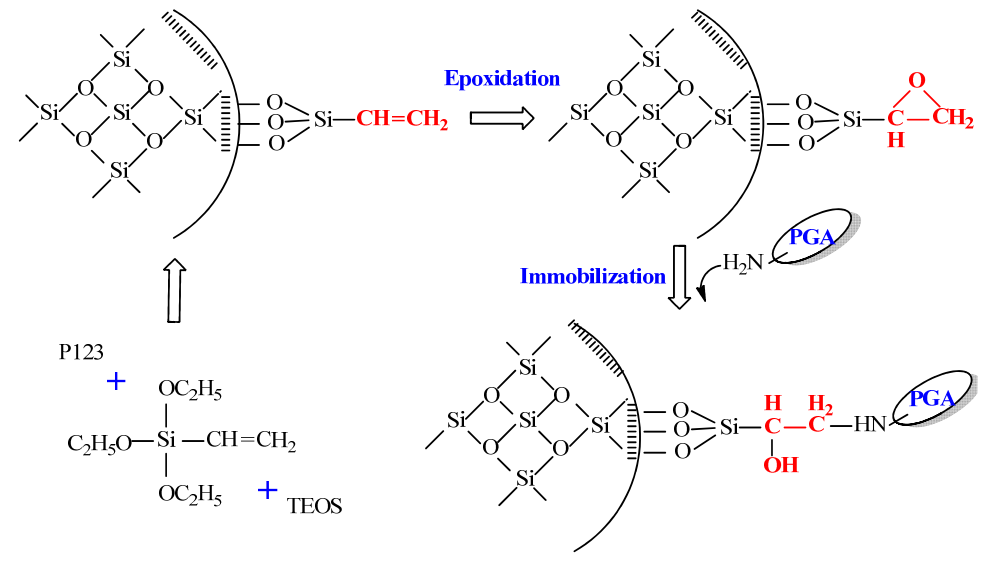

Vinyl functionalized mesoporous silica was synthesized and the vinyl groups were epoxidized to prepare epoxy functionalized mesoporous silica, which is an effective support for the immobilization of enzyme through chemical bonding.

\section{References}

[1] Bornscheuer U T. Angew Chem Int Ed, 2003, 42: 3336

[2] DiCosimo R, McAuliffe J, Poulose A J, Bohlmann G. Chem Soc Rev, 2013, 42: 6437

[3] Katchalski-Katzir E, Kraemer D M. J Mol Catal B, 2000, 10: 157

[4] Cao L Q. Curr Opin Chem Biol, 2005, 9: 217

[5] An Z, He J, Lu S, Yang L. AIChE J, 2010, 56: 2677

[6] Liese A, Hilterhaus L. Chem Soc Rev, 2013, 42: 6236

[7] Liu X H, Bu C H, Nan Z H, Zheng L C, Qiu Y, Lu X Q. Talanta, 2013, 105: 63

[8] He J, Song Z H, Ma H, Yang L, Guo C X. J Mater Chem, 2006, 16: 4307

[9] Yiu H H P, Wright P A. J Mater Chem, 2005, 15: 3690

[10] Hartmann M. Chem Mater, 2005, 17: 4577

[11] On D T, Desplantier-Giscard D, Danumah C, Kaliaguine S. Appl Catal A, 2001, 222: 299

[12] Hartmann M, Jung D. J Mater Chem, 2010, 20: 844

[13] Kim J, Grate J W, Wang P. Chem Eng Sci, 2006, 61: 1017

[14] Chong A S M, Zhao X S. Appl Surf Sci, 2004, 237: 398

[15] Yiu H H P, Wright P A, Botting N P. J Mol Catal B, 2001, 15: 81

[16] Wight A P, Davis M E. Chem Rev, 2002, 102: 3589

[17] Ispas C, Sokolov I, Andreescu S. Anal Boianal Chem, 2009, 393: 543

[18] Stein A, Melde B J, Schroden R C. Adv Mater, 2000, 12: 1403

[19] Burkett S L, Sims S D, Mann S. Chem Commun, 1996: 1367

[20] Macquarrie D J. Chem Commun, 1996: 1961

[21] Hoffmann F, Cornelius M, Morell J, Froba M. Angew Chem Int Ed, 2006, 45: 3216

[22] Lim M H, Stein A. Chem Mater, 1999, 11: 3285

[23] Sakaguchi K, Matsui M, Mizukami F. Appl Microbiol Biotechnol, 2005, 67: 306

[24] Miyahara M, Vinu A, Ariga K. J Nanosci Nanotechnol, 2006, 6: 1765

[25] Sheldon R A, van Pelt S. Chem Soc Rev, 2013, 42: 6223

[26] Sayari A, Hamoudi S. Chem Mater, 2001, 13: 3151

[27] Huh S, Wiench J W, Yoo J C, Pruski M, Lin V S Y. Chem Mater, 2003,

\section{5: 4247}

[28] MacLachlan M J, Asefa T, Ozin G A. Chem-Eur J, 2000, 6: 2507

[29] Wang J, Zou Y C, Sun Y, Hemgesberg M, Shffner D, Gao H C, Song X J, Zhang W X, Jia M J, Thiel W R. Chin J Catal (王静, 邹永存, 孙渝, Hemgeserg M, Shffner D, 高洪成, 宋晓静, 张文祥, 贾明君, Thiel W R. 催化学报), 2014, 35: 532

[30] Cai W J, Zhou Y, Bao R L, Yue B, He H Y. Chin J Catal (蔡雯佳, 周琰, 包任烈, 岳斌, 贺鹤勇. 催化学报), 2013, 34: 193

[31] Richer R. Chem Comm, 1998: 1775

[32] Hoffmann F, Cornelius M, Morell J, Froba M. J Nanosci Nanotechnol, 2006, 6: 265

[33] Mateo C, Fernandez-Lorente G, Abian O, Fernandez-Lafuente R, Guisan J M. Biomacromolecules, 2000, 1: 739

[34] Boller T, Meier C, Menzler S. Org Process Res Dev, 2002, 6: 509

[35] Lü Y J, Lu G Z, Wang Y Q, Guo Y L, Guo Y, Zhang Z G, Wang Y S, Liu X H. Adv Funct Mater, 2007, 17: 2160

[36] Xue P, Xu F, Xu L D. Appl Surf Sci, 2008, 255: 1625

[37] Wang Y Q, Zibrowius B, Yang C M, Spliethoff B, Schüth F. Chem Commun, 2004: 46

[38] Wang Y Q Yang C M, Zibrowius B, Spliethoff B, Linden M, Schüth F. Chem Mater, 2003, 15: 5029

[39] Xia L Y, Zhang M Q Rong M Z, Xu W M. Phys Chem Chem Phys, 2010, 12: 10569

[40] Schwartz N N, Blumbergs J H. J Org Chem, 1964, 29: 1976

[41] Asefa T, Kruk M, MacLachlan M J, Coombs N, Grondey H, Jaroniec M, Ozin G A. Adv Funct Mater, 2001, 11: 447

[42] Pang J B, Hampsey J E, Hu Q Y, Wu Z W, John V T, Lu Y F. Chem Commun, 2004: 682

[43] Ryoo R, Joo S H, Kim J M. J Phys Chem B, 1999, 103: 7435

[44] Kleitz F, Choi S H, Ryoo R. Chem Commun, 2003: 2136

[45] Xue P, Lu G Z, Guo Y L, Wang Y S, Guo Y.J Mol Catal B, 2004, 30: 75

[46] Yang C M, Zibrowius B, Schüth F. Chem Commun, 2003: 1772

[47] Yang C M, Zibrowius B, Schmidt W, Schüth F. Chem Mater, 2004, 16: 2918

[48] Yang C M, Smatt J H, Zibrowius B, Linden M. New J Chem, 2004, 28: 
1520

[49] Webb P A, Orr C. Analytical Methods in Fine Particle Technology. Norcross: Micromertics Instrument Corporation, 1997. 53
[50] Shimada T, Aoki K, Shinoda Y, Nakamura T, Tokunaga N, Inagaki S, Hayashi T. J Am Chem Soc, 2003, 125: 4688

[51] Zhao X S, Lu G Q.J Phys Chem B, 1998, 102: 1556

\title{
乙烯基Ia3d介孔硅分子篮的环氧化及其固定化青霉素酰化酶
}

\author{
詹望成，吕勇军，杨玲，郭杨龙，王艳芹，郭 耘，卢冠忠 ${ }^{*}$
}

华东理工大学工业催化研究所, 结构可控先进功能材料及其制备教育部重点实验室, 上海200237

摘要: 采用直接共聚法合成表面含有乙烯基的具有立方相I $I a 3 d$ 结构的介孔硅分子篮(V-ClMS), 然后对乙烯基团进行环氧化制备 得到表面环氧基功能化的介孔硅分子篎(E-CIMS), 采用X射线衍射、 $\mathrm{N}_{2}$ 吸附-脱附、透射电镜、热重分析和 ${ }^{13} \mathrm{C}$ 固体核磁共振对制 备的介孔硅分子篮进行了表征. 结果表明, 表面含有乙烯基的V-CIMS介孔硅分子篮能被一步成功合成, 并易于发生环氧化而获 得表面环氧基功能化的E-CIMS介孔硅分子篮. 将E-CIMS介孔硅分子篮作为载体用于固定化青霉素G酰化酶(PGA), 研究了表面 环氧基团对固定化PGA初活性和操作稳定性的影响. 结果表明, 随着表面环氧基团数量的增加, 介孔硅分子篮孔径减小, 表面疏 水性增加, 导致载酶量和初活性减小. 但介孔硅分子篎表面适量的环氧基团能增强E-CIMS介孔硅分子篎与PGA之间的相互作用, 从而提高固定化PGA的操作稳定性.

关键词: 直接共聚法; 介孔硅分子筛; 酶; 固定化; 青霉素酰化酶

收稿日期: 2014-03-24. 接受日期: 2014-04-15. 出版日期: 2014-10-20.

*通讯联系人. 电话/传真: (021)64252923; 电子信箱: gzhlu@ecust.edu.cn

基金来源：国家自然科学基金(21103048); 新世纪优秀人才支持计划(NCET-09-0343); 上海市教育发展基金会 “曙光学者” 计划 (10SG30).

本文的英文电子版由Elsevier出版社在ScienceDirect上出版(http://www.sciencedirect.com/science/journal/18722067). 